\title{
Medical Training Experience and Expectations Regarding Future Medical Practice of Medical Students at the University of Cape Verde
}

\section{A Experiência de Formação Médica e Expectativas Sobre o Futuro da Prática Médica dos Estudantes de Medicina na Universidade de Cabo Verde}

António Pedro DELGADO $\square^{1,2}$, Antonieta Soares MARTINS ${ }^{1}$, Paulo FERRINHO ${ }^{2,3}$

Acta Med Port 2017 Oct;30(10):699-703 - https://doi.org/10.20344/amp.8179

\section{ABSTRACT}

Introduction: Cape Verde is a small insular developing state. Its first experience of undergraduate medical education began in October 2015. The purpose of this paper is to describe and analyze the professional expectations and profile of the first class of medical students at the University of Cape Verde.

Material and Methods: A piloted, standardized questionnaire, with closed and open-ended questions, was distributed to registered medical students attending classes on the day of the survey. All data were analyzed using SPSS.

Results: Students decided to study medicine in their mid-teens with relatives and friends having had significant influence over their decisions. Other major reasons for choosing medical training include "to take care of other people", "fascination for the subject matters of medicine" and "I have always wanted to". The degree of feminization of the student population is extremely high (20/25; $80.0 \%)$. Medical students are in general satisfied with the training program, and have expectations that the training received will allow them to be good professionals. Nevertheless, they consider the course too theoretical. Medical students know that this represents an opportunity for them to contribute to public welfare. Nonetheless, their expectations are to combine public sector practice with private work. Medical students come mostly from Santiago Island where the Capital of the Country is located. They still do not know about their future area of specialization. But all of those who want to specialize want to do so abroad. They mostly expect to follow hospital careers rather than health administration or family and community medicine.

Discussion: This study contributes to the growing body of knowledge about medical students' difficulties and expectations regarding medical schools or curriculums in lusophone countries. The decision to invest in the training of local physicians is justified by the need to be less dependent on foreigners. Local postgraduate medical training programs are already considered a priority for the immediate future.

Conclusion: Cape Verde is pursuing a bold strategy to deal with a shortage of medical doctors. The problems experienced by medical students provide an important insight to help the new medical school to provide a better learning environment for students. The fact that students are not sure about their future area of specialization is an opportunity to guide them towards the areas of the health system with pressing needs. The current feminization of the medical workforce will be sustained with the profile of the present intake, hence the need to take this into account in workforce planning.

Keywords: Cape Verde; Career Choice; Education, Medical; Students, Medical; Surveys and Questionnaires

\section{RESUMO}

Introdução: Cabo Verde é um pequeno estado insular em desenvolvimento. A sua primeira experiência em educação médica prégraduada começou em outubro de 2015. O objetivo deste artigo é descrever e analisar as expectativas profissionais e o perfil da primeira turma de estudantes de medicina na recente escola de medicina de Cabo Verde.

Material e Métodos: Um questionário padronizado, dirigido, com perguntas fechadas e abertas, foi distribuído aos estudantes de medicina inscritos que frequentaram as aulas no dia da pesquisa. Todos os dados foram analisados usando SPSS.

Resultados: Os alunos decidiram estudar medicina a meio da adolescência. Parentes e amigos parecem ter tido uma influência importante nessa decisão. Outras razões principais para escolher a formação médica incluem "para cuidar de outras pessoas", "fascínio para os assuntos da medicina" e "meu desejo desde sempre". O grau de feminização dessa população estudantil é extremamente alta $(20 / 25 ; 80,0 \%)$. Os estudantes de medicina estão, em geral satisfeitos com o programa de formação e têm expectativas de que a formação recebida Ihes permitirá ser bons profissionais. No entanto, eles consideram o curso muito teórico. Os estudantes de medicina consideram que isso pode representar a sua oportunidade para contribuir para o bem-estar público e suas expectativas são para combinar o uso do sector público com o trabalho privado. Os estudantes de medicina vieram principalmente da ilha de Santiago, onde está localizada a capital do país e que também é o local preferido para a prática futura. Eles ainda não decidiram sobre a sua futura área de especialização. Mas todos aqueles que querem se especializar, querem fazê-lo no estrangeiro. A maioria deles espera seguir carreira hospitalar em vez de trabalho baseado na administração de saúde ou nos centros de saúde.

Discussão: Este estudo contribui para o crescente conhecimento sobre as dificuldades do estudante de medicina e expectativa das escolas médicas ou programas de ensino médico nos países lusófonos. A decisão de investir na formação local de médicos justificase pela necessidade de se ser menos dependente do estrangeiro no processo. Programas locais de pós-graduação médica são considerados uma prioridade para o futuro imediato.

1. Serviços Académicos. Universidade de Cabo Verde. Praia. Cape Verde.

2. Global Health and Tropical Medicine. Instituto de Higiene e Medicina Tropical. Universidade NOVA de Lisboa. Lisbon. Portugal.

3. World Health Organization Collaborating Centre on Health Workforce Policy and Planning - GHTM. Genebra. Switzerland.

$\triangle$ Autor correspondente: António Pedro Delgado. apc_delgado@hotmail.com

Recebido: 03 de setembro de 2016 - Aceite: 16 de junho de 2017 | Copyright @ Ordem dos Médicos 2017 
Conclusão: Cabo Verde está a seguir uma estratégia ousada para se recuperar de seu déficit em médicos. Os problemas sentidos pelos estudantes de medicina são um importante ponto de vista para ajudar a nova escola de medicina a proporcionar um melhor ambiente de aprendizagem para os alunos. O facto de os alunos não terem ainda uma certeza sobre a sua futura área de especialização é uma oportunidade para orientá-los para as necessidades prementes do sistema de saúde. O perfil da presente entrada para esse curso sustenta a actual feminização da força de trabalho médica, daí a necessidade de levar isso em conta no planeamento da força de trabalho.

Palavras-chave: Cabo Verde, Educação Médica; Estudantes de Medicina; Especialização; Satisfação

\section{INTRODUCTION}

Cape Verde is a small insular developing state (SIDS) which has been very successful in its health policy, achieving the best health status indicators of Sub-Saharan African countries. ${ }^{1}$ Nevertheless, Cape Verdean doctors have always trained abroad since before political independence in 1975. At the time of independence, Cape Verde had 13 doctors. The cumulative total increased to 401 doctors listed in the department of human resources database of the Ministry of Health on the $31^{\text {st }}$ of December 2014. The 401 doctors who make up this contingent graduated from 99 higher education institutions in 17 countries. Five countries trained $378(94.3 \%)$ of the doctors in the database. The remaining 23 received their training in 12 other countries. Cuba appeared with the highest number of graduates $(189,47.1 \%)$, almost half of the country's doctors. Portugal contributed to the training of $78(19.5 \%)$. Brazil came third, training $76(19.0 \%)$ Cape Verdean doctors. The former Union of Soviet Socialist Republics (USSR) comes $4^{\text {th }}$ having trained $36(9.0 \%)$ Cape Verdean doctors. The same clustering pattern is observed for specialist training. ${ }^{2}$

Possible achievements in health have thus been constrained by quantitative and especially qualitative gaps in terms of human resources due to the total reliance on foreign countries to train and specialize medical doctors, at a tremendous cost to the country.

The first experience of pre-graduate medical education in the country began in October 2015 with major support from the Faculty of Medicine of Coimbra (FMUC), Portugal, which set out to replicate at the University of Cape Verde (Uni-CV) the model of medical education developed by the University of the Azores, which is also supported by the FMUC. Under this model, students take classes in Cape Verde in the first three years and travel afterwards to Portugal, where they study two more years, allowing them to gain clinical teaching experience in a large European academic hospital. The last year of clinical practice is completed back in Cape Verde. The work of the FMUC will involve, above all, supervision, monitoring of the process and involvement where needed. The project will also feature the collaboration of eight Portuguese teachers (including some from IHMT-UNL). The expectation of Uni$\mathrm{CV}$ is that, beyond direct support in the course work, this collaboration will provide structure and offer a purpose from the beginning, to promote transfer of knowledge, namely to contribute to the establishment of an independent local faculty.

This paper describes the socio-economic profile of medical students admitted in October 2015 to the first undergraduate medical degree program ever run in Cape
Verde, with the objective of identifying their social and geographical origins and their difficulties regarding their education and expectations about their professional future. These are important in order to allow, early on in the phase of implementation of medical education, the identification of learning problems and difficulties that should be corrected in future editions of the medical course. Knowing where students come from might help to anticipate future distortions in the distribution of the medical workforce. ${ }^{3}$ Expectations regarding their professional future should be accommodated not only in their medical training, but also in the processes of health workforce planning of the Ministry of Health.

\section{MATERIAL AND METHODS}

The methodology is similar to the one utilized in analogous surveys in Angola, Guinea-Bissau, Mozambique and Timor-Leste. ${ }^{4-9}$ We conducted a survey among medical students of the first class of the first medicine course of the University of Cape Verde. A piloted, standardized (during the previous surveys mentioned above), self-administered questionnaire, with closed and open-ended questions, was distributed to registered medical students attending classes on the day of the survey during May 2016. One of the authors (AM) was present to distribute and collect the questionnaires and to answer queries from the respondents.

Twenty-five anonymous questionnaires were distributed and collected by one of the authors. The response rate was $100 \%$. All data were entered into Excel (2013) and analyzed using SPSS 23 . The statistical analysis is mainly descriptive.

The main variables analyzed included: students' reasons for studying medicine; main difficulties experienced during the first year of training; satisfaction with the academic training received; expectations regarding future place of practice, specialization and income.

The questionnaire (available on request from the corresponding author) included an assessment of the training received in terms of the satisfaction with variables listed in Table 1, based on five levels of probability of choice: $1=$ very low, 2 = low, $3=$ moderate, $4=$ high, and $5=$ very high.

\section{RESULTS}

\section{Students' background}

A significant proportion of students was born $(64 \%)$ and received their primary $(68 \%)$ and secondary $(72 \%)$ school education on Santiago Island where Praia, the capital city, is located [hence the observation that the vast majority of 
Table 1 - Medical students' assessment of the training received, University of Cape Verde, 2015

\begin{tabular}{|c|c|c|c|c|c|}
\hline \multirow[b]{2}{*}{ Questions } & \multicolumn{5}{|c|}{$\begin{array}{l}\text { Likert scale } \\
(1=\text { very unhappy and } 5=\text { very satisfied })\end{array}$} \\
\hline & 1 & 2 & 3 & 4 & 5 \\
\hline Satisfaction with weekly teaching burden and timetable & 2 & 5 & 10 & 7 & 1 \\
\hline Satisfaction with teaching program & 1 & 3 & 7 & 11 & 3 \\
\hline Satisfaction with quality of the teachers & 0 & 2 & 11 & 10 & 2 \\
\hline Satisfaction with support systems (computers, library, laboratories ...) & 5 & 7 & 9 & 2 & 2 \\
\hline
\end{tabular}

students ( $56 \%$, no data for $28 \%$ ) is accommodated with their families - all the others are in private rented accommodation as there are no university dormitories], where the medical school is located, although Santiago only concentrates about 56\% of the country's population (according to 2015 data from the Government's Statistical Office).

The vast majority of students were female (80\%) and $68 \%$ were aged between 19 and 23, 20\% were under 18 and $8 \%$ were 24 or older (no data for one student); only one $(4 \%)$ student was married and another one studied and worked at the same time.

\section{The decision to study medicine}

Most students (83\%) took their decision to study medicine when they were aged 17 or under and about one third $(35 \%)$ at the age of 12 or under.

The main reasons to choose medicine as a profession (more than one possible reason) were "to care for others, to contribute to public welfare " $(52 \%)$, "family influences" $(40 \%)$, "fascination for the subject matters of medicine" (36\%), "self-realization and vocation" (32\%), "to meet the needs of the country" (20\%), "social recognition" and "favorable labor market" (12\% each).

Most $(56 \%)$ of the students reported having relatives that have some association with the health sector (only $26 \%$ of these were doctors). As reported above, these relatives were acknowledged as an important influence on their decision to choose medicine as their field of training.

\section{Main difficulties reported}

The students reported difficulty with academic work, as they felt that their secondary education had not prepared them to study at university. Some mentioned that they had difficulty prioritizing the study materials and did not know how to cope with the amount of work and self-study expected from them.

Only $16 \%$ of the students were satisfied or very satisfied with the academic support systems. The most frequent difficulties reported by the students were: "lack of bibliography", "inadequate libraries", limited "access to laboratories" and inability to "dissect cadavers to study anatomy" (Table 1).

Except for a working student and another foreign student supported by their parents, all the other students did not consider the course fees excessive. Seventy percent reported receiving a bursary from the Cape-Verdean government.

\section{Satisfaction with the academic education received}

Only $32 \%$ of the students were satisfied or very satisfied with the burden of lectures and with the timetable and $56 \%$ with the course program. Regarding the training received, $84 \%$ felt it was too theoretical and only $48 \%$ felt satisfied or very satisfied with the quality of the lecturers, although they believed it prepared them to work as doctors anywhere in the world (72\%) (Table 1).

\section{Expectations regarding their professional future and income}

When asked about their intentions regarding the sectors where they would like to practice medicine after completing their medical education, the proportion of students interested in exclusively public-sector work was low $(12 \%)$ and, with two exceptions (8\%), private-sector work was considered only in conjunction with a publicsector appointment (76\%). Most $(72 \%)$ would like to work in a hospital environment, $18 \%$ in family and community medicine and $8 \%$ in governance of the health system. One wanted to combine hospital with health center practice.

As expected, $64 \%$ of students wanted to practice on Santiago Island after graduation. Of those born in Santiago, $78 \%$ wanted to practice in Santiago after graduation and $22 \%$ want to emigrate. Emigration to work abroad was the intention of $25 \%$ of the male students $(1 / 4)$ and $17 \%$ of the female students $(3 / 16)$.

Most $(76 \%)$ wanted to specialize, but only one knew that she wanted to specialize in cardiology. Of the 19 already considering specialization after graduation, the countries of choice for specialist training were: Portugal (53\%), USA and Brazil (16\% each), Cuba (11\%) and 1, the United Kingdom (5\%).

Only $5 \%$ of students considered that a fair level of monthly income immediately after graduation would be similar to the current starting salary for doctors in the public sector: the expectation was to earn a higher income right from the first year of practice. This was actually one of the reasons given to wanting to work in private practice.

\section{DISCUSSION}

Cape Verde is pursuing a bold strategy to deal with a shortage of medical doctors. The decision to invest in the local training of more physicians is justified by the authorities of Cape Verde by the need to be less dependent on foreigners and to attain a density and quality of physicians compatible with their high level of ambition for the health sector. 
This study contributes to the growing body of knowledge about the difficulties of medical students and expectation regarding medical schools or curriculums in lusophone countries. ${ }^{6-11}$ Some of the differences between the observations of this study and of other similar studies must be interpreted taking into consideration that this paper focuses on first year medical students, while the results of other studies refer to several academic years of the medical program. This and the sample size of 25 students are the main limitations of this study. Nevertheless, the 25 students represent a $100 \%$ response rate of all students registered for medical training. Hence, the results presented are 'true' results of the group under study and not estimated probabilities.

As described for Mozambique and Timor-Leste, ${ }^{4,9}$ the data suggest that an individual educational strategy - from primary to secondary education - that brings scholars nearer to Santiago, the island where the university is located, represents a personal advantage in terms of getting selected for medical school.

Similar to the results in other Portuguese-speaking countries, ${ }^{4-9}$ motivations for choosing the medical profession are linked to social commitment, self-realization and perceptions of opportunities related to the health labor market (shortage of doctors). What seems unique is the weight of fascination with greater scientific knowledge about the human body and medical sciences.

Like findings from other surveys: i) there is a predominance of female students, but much more marked in Cape Verde than in the other countries where the survey has been carried out; ii) relatives working in the healthcare sector are an important influence in the choice of the medical profession; iii) and there is great dissatisfaction with academic support systems. ${ }^{4-9,10}$

The current trend of feminization of the CapeVerdean medical workforce has been described ${ }^{11-16}$ and will be accentuated by the intake profile described in this paper. Feminization of the student body is an important consideration with implications for career choices. Female doctors seem most likely to remain in exclusive publicsector practice and they are less likely to go abroad for specialist training. The data from this study are aligned with this observation, but the numbers are too small to allow for firm conclusions. On the other hand, they show less availability for overtime work and for work in rural and remote areas. ${ }^{11-17,18}$

Similar to other African surveys ${ }^{4-8,19-25}$ are the high levels of dissatisfaction with the program and the workload. It seems that both students and teachers need support on how to learn and teach. The complaint about the quality of secondary education points to the need to consider educational intervention at the level of secondary education and/or pre-university preparatory classes for the students selected for the medical training program.

The percentage with government bursaries is also much higher than in other medical training programs in Angola and Mozambique, but lower than in Timor-Leste. .-9 $^{-9}$
Our results also correspond to findings from other surveys that most students would prefer to settle for hospital-based practice and work in the public sector. ${ }^{10,14-18}$

As for this study, other studies ${ }^{7-9,28}$ reported that many students were not sure of their future area of specialization. In many other developing countries, the critical step in the migration of medical graduates is the moment when they decide to obtain specialized training: a frequent individual decision is to look for it abroad, , ${ }^{728-30}$ leading to a subsequent decision to stay in the host country. ${ }^{28}$ Reflecting the lack of specialist training in the country, students in Cape Verde would like to obtain specialized training abroad. Hence, local postgraduate medical training programs are already considered a priority for the immediate future.

Salary expectations are inflated, a consideration that suggests that newly graduated doctors will look for other sources of income to complement their public-sector salaries. ${ }^{7,9}$

\section{CONCLUSIONS}

Medical students felt problems are an important insight for helping the new medical school to correct its course and provide a better learning environment for students. Medical students are in general satisfied with the training received, although they demand improvements in terms of systems to support their studies and training - libraries, laboratories and pedagogical training of their teachers. Some students mention that they do not know how to study, pointing to the need to develop support and coaching systems with experienced teachers or more senior students.

The fact that students are not sure about their future area of specialization implies an opportunity to guide them towards the pressing needs of the health system, in terms of priority specialties such as family medicine, counteracting the hospital orientation of the students.

The production of local doctors who wish to combine work in the public sector with work in the private sector points to the need for the health system to strengthen market and professional regulatory mechanisms.

The current feminization of the medical workforce will be sustained with the profile of the present intake, hence the need to take this into account in workforce planning and student selection.

The risk for maldistribution of the workforce considering the geographical origin of medical students and their preferred island for future practice should also be a consideration in workforce planning and in the criteria for student selection.

\section{ACKNOWLEDGMENTS}

The Tutorial Commission of the doctoral program of APD (A. Corsino Tolentino, Sónia Dias and Giuliano Russo); students of the first medical school in Cape Verde who completed the questionnaire; Ministry of Health of Cape Verde and Instituto de Higiene e Medicina Tropical da Universidade Nova de Lisboa, for the support. 


\section{HUMAN AND ANIMAL PROTECTION}

The authors declare that the followed procedures were according to the regulations established by the responsible body of the Ethics and Clinical Research Committee and according to the Helsinki Declaration of the World Medical Association.

\section{DATA CONFIDENTIALITY}

The authors declare that they have followed the protocols of their work center on the publication of patient data.

\section{REFERENCES}

1. World Health Organization. Cabo Verde Factsheets of Health Statistics. WHO. 2010. (390.21 kB). [accessed 2016 Jun 24]. Available from: http://www.afro.who.int/index.php?option=com_docman\&task=doc_ download\&gid=7092\&ltemid=2593.

2. Delgado AP, Tolentino AC, Ferrinho P. The evolution of the medical workforce in Cape Verde since independence in 1975. Hum Resour Health. 2017;15:5.

3. Dussault G, Franceschini MV. Not enough there, too many here: understanding geographical imbalances in the distribution of the health workforce. Hum Resour Health. 2006; 4:12.

4. Sousa Jr F, Schwalbach J, Adam Y, Gonçalves L, Ferrinho P. The training and expectations of medical students in Mozambique. Hum Resour Health. 2007;5:11.

5. Ferrinho P, Fronteira I, Sidat M, Hipólito F, Mercer H, Dussault G. Formação médica em Moçambique: realidade e expectativas. Rev Med Moçambique. 2010;10:S52-8.

6. Ferrinho P, Fronteira I, Sidat M, de Sousa Jr F, Dussault G. Profile and professional expectations of medical students in Mozambique: a longitudinal study. Hum Res Health. 2010;8:21.

7. Ferrinho P, Sidat M, Fresta MJ, Rodrigues A, Fronteira I, da Silva F, et al. The training and expectations of medical students in Angola, GuineaBissau and Mozambique. Hum Resour Health. 2011;9:9.

8. Fronteira I, Rodrigues A, Pereira C, Silva AP, Mercer H, Dussault G, et al. Realities and professional expectations of medical students attending Guinea Bissau's medical school in 2007 school year. Acta Med Port. 2011;24:265-70.

9. Dambisya YM. Career intentions of UNITRA medical students and their perceptions about the future. Educ Health. 2003;16:286-97.

10. Huhn D, Huber J, Ippen FM, Eckart W, Junne F, Nikendei C. International medical students' expectations and worries at the beginning of their medical education: a qualitative focus group study. BMC Med Educ. 2016;16:33.

11. Phillips SP, Austin EB. The feminization of medicine and population health. JAMA. 2009;301:863-4.

12. Gjerberg E. Gender similarities in doctors' preferences and gender differences in final specialization. Soc Sci Med. 2002;54:591-605.

13. Fukuda Y, Harada T. Gender differences in specialty preference and mismatch with real needs in Japanese medical students. BMC Med Educ. 2010;10:15.

14. Lambert EM, Holmboe ES. The relationship between specialty choice and gender of U.S. medical students, 1990-2003. Acad Med. 2005;80:797-802.

15. Dorsey ER, Jarjoura D, Rutecki GW. The influence of controllable lifestyle and sex on the specialty choices of graduating U.S. medical

\section{CONFLICTS OF INTEREST}

Antonieta Soares Martins is the Director of the Medical Program at the Universidade de Cabo Verde. All other authors declare no conflicts of interest.

\section{FINANCIAL SUPPORT}

Fundação Calouste Gulbenkian. Fundação para a Ciência e Tecnologia (project GHTM - UID/Multi/04413/ 2013).

students, 1996-2003. Acad Med. 2005,80:791-6.

16. Buddeberg-Fischer B, Klaghofer R, Abel T, Buddeberg C. The influence of gender and personality traits on the career planning of Swiss medical students. Swiss Med Wkly. 2003;133:535-40.

17. Schwartz RW, Jarecky RK, Strodel WE, Haley JV, Young B, Griffen WO, Jr. Controllable lifestyle: a new factor in career choice by medical students. Acad Med. 1989;64:606-9.

18. Adegoke OA, Noronha C. University pre-medical academic performance as predictor of performance in the medical school: a case study at the College of Medicine of the University of Lagos. Nigerian J Health Biomed Sci. 2002;1:49-53.

19. Russo G, Ferrinho P, De Sousa B, Conceição C. What influences national and foreign physicians' geographic distribution? An analysis of medical doctors' residence location in Portugal. Hum Resour Health. 2012;10:12.

20. Ayeni O. A comparative study of the performance of direct and confessionals entrants into the University of Ibadan Medical School 1959-69. Br J Med Educ. 1972;6:277-85.

21. Bamgboye EA, Ogunowo BE, Badru OB, Adewoye EO. Students' admission grades and their performance at Ibadan University preclinical MBBS Examinations. Afr J Med Sci. 2001;30:207-11.

22. Nwoha PI. Students' attitude and predictor of performance in anatomy. Afr J Med Sci. 1992;21:41-5.

23. Olaleye SB, Salami HA. Predictor of academic performance in the pre-clinical sciences: effects of age, sex and mode of admission at the Maiduguri Medical School. Afr J Med Sci. 1997;26:189-90.

24. Oyebola DD, Adewoye OE. Preference of preclinical medical students for medical specialities and the basic medical sciences. Afr J Med Sci. 1998;27:209-12.

25. Salahdeen HM, Murtala BA. Relationship between admission grades and performances of students in the first professional examination in a new medical school. Afric J Biomed Res. 2005;8:51-7.

26. Dambisya YM. Career intentions of UNITRA medical students and their perceptions about the future. Educ Health. 2003;16:286-97.

27. Liang D, Tang CX. The specialty choice of medical students in China: a stated preference experiment. BMC Med Educ. 2016;16:107.

28. Buchan J, McPake B, Mensah K, Rae G. Does a code make a difference - assessing the English code of practice on international recruitment? Hum Resour Health. 2009;7:33.

29. Akl EA, Maroun SM, Afif C, Abdo A, Choucair J, Sakr C, et al. Postgraduation migration intentions of students of Lebanese medical schools: a survey study. BMC Public Health. 2008;8:191.

30. Rao NR, Rao UK, Cooper RA. Indian medical students' views on immigration for training and practice. Acad Med. 2006;81:1278-84. 